\title{
ANALISIS FAKTOR-FAKTOR YANG MEMPENGARUHI PENDAPATAN ASLI DAERAH (PAD) KABUPATEN MIMIKA
}

\author{
Hengki Derek Wandosa ${ }^{1}$ \\ Wandosah@yahoo.com \\ Arius Kambu ${ }^{2}$ \\ ariusk16@gmail.com \\ Agustinus Numberi ${ }^{3}$ \\ numberi.agus75@gmail.com
}

\begin{abstract}
This study aims to determine: (1) The potential revenue (PAD) in Mimika Regency Year 2002-2013; (2) Identify the factors that encourage the growth source revenue (PAD) in Mimika. The method used in analyzing the use of quantitative techniques the 4 quadrant approach to tax (shift and share), elasticity component of revenue $(P A D)$. The results showed that, by classification using the shift and share analysis of the potential components of taxes and levies in Mimika, shows the classification Prima namely Public service levies, and levies Licensing Certain, whereas in the classification Potentially the service levies Enterprises, for the classification of Developing the components Restaurant tax, entertainment tax, advertisement tax, street lighting tax and the classification Retarded Hotel Tax Non Metallic Minerals \& Rocks. Based on the calculation of tax elasticity against the regional revenue, obtained information that the sources of growth by component Local Revenue (PAD) that is the average of the component Local Tax gain an Elastic (2.91> $1)$, Retribution gain an Inelastic $(0.22<1)$, Earnings and Asset enterprises have a unitary assessment $(1.98=1)$, and a component of Other Income, Legal acquire Elastic assessment (-16.79> 1). So that through this information, the source of regional revenue growth in Mimika courtesy Realization component Local Tax, Income and Asset enterprises.
\end{abstract}

Keywords : Local Revenue

\section{PENDAHULUAN}

Pendapatan Asli Daerah (PAD) merupakan tolak ukur yang penting untuk menentukan tingkat kemampuan daerah dalam melaksanakan otonomi daerah secara nyata dan bertanggungjawab. Otonomi daerah membawa dampak positif bagi daerah yang memiliki potensi sumber daya alam, tetapi tidak demikian dengan daerah yang miskin sumber daya alamnya, yang merupakan salah satu masalah yang dihadapi pemerintah daerah kabupaten/kota pada umumnya adalah terbatasnya dana yang berasal dari daerah sendiri (PAD), sehingga proses otonomi daerah belum bisa berjalan sebagaimana mestinya (Azis,1997).

\footnotetext{
${ }^{1}$ Alumni Mahasiswa Magister Keuangan Daerah Universitas Cenderawasih

2 Staf Dosen Jurusan IImu Manajemen Fakultas Ekonomi \& Bisnis Universitas Cenderawasih

${ }^{3}$ Staf Dosen Jurusan IImu Manajemen Fakultas Ekonomi \& Bisnis Universitas Cenderawasih
} 
Dalam penyelenggaraan otonomi daerah nantinya dikhawatirkan banyak daerah kabupaten/kota yang tidak mampu membiayai kebutuhan daerahnya. Hal ini dapat dilihat dari kondisi keuangan daerah yang ada selama ini di mana porsi antara PAD dengan bantuan pusat sangat menjolok sekali bahwa lebih separuh dari jumlah kabupaten/kota di Indonesia memiliki Pendapatan Asli Daerah (PAD) yang sangat minim dalam membelanjai kebutuhan anggaran daerahnya, yaitu di bawah $15 \%$ dari total anggaran secara keseluruhan.

Kabupaten Mimika yang merupakan salah satu Kabupaten di Provinsi Papua juga diberi kewenangan untuk mengatur dan mengelola sumber pendapatan daerahnya sendiri. Untuk kelangsungan dan kemajuan dari Kabupaten Mimika maka diharapkan Kabupaten Mimika mampu menggali, mengelola, dan memaksimalkan potensi sumber daya. Kabupaten Mimika adalah salah satu Kabupaten di Provinsi Papua yang memiliki sumber daya alam yang melimpah. Sektor utama perekonomian di Kabupaten Mimika adalah pertambangan. Dimana salah satu perusahaan terbesar di dunia yakni PT. Freeport Indonesia sedang melakukan produksi diwilayah administrasi Kabupaten Mimika,

Perkembangan PDRB atas dasar harga konstan secara faktual bahwa terjadi penurunan pada tahun 2010 sebesar Rp. 10 Triliun Sedangkan penerimaan Pendapatan Asli Daerah (PAD) Kabupaten Mimika mengalami peningkatan pada tahun 2010 sebesar Rp.96 Milyar dan kemudian naik secara cukup signifikan pada tahun 2011 sebesar Rp.135 Milyar dan pada tahun 2012 sebesar Rp.337 milyar, dan selanjutnya bahwa pada tahun 2013 cukup signifikan terjadi penurunan Penerimaan PAD Kabupaten Mimika sebesar Rp.126 Milyar.

Komponen Pajak Daerah pada tahun 2012 mampu menyumpangkan Rp.147 Milyar pada pembentukan nilai PAD Kabupaten Mimika, pada tahun 2010 Retribusi memberikan kontribusi sebesar Rp.18 Milyar, dan Komponen Laba BUMD dan Asset Daerah sebesar Rp.6 Milyar pada tahun 2013, sedangkan komponen Pendapatan Lain-lain yang sah sebesar Rp.176 Milyar pada tahun 2012. Titik nilai realisasi komponen PAD ini menandakan bahwa sebenarnya masih terdapat komponen pajak, retribusi serta laba BUMD yang masih perlu didorong untuk dapat memberikan kontribusi fiskal melalui SKPD terkait di Kabupaten Mimika. Sepertinya halnya yang disampaikan melalui media oleh Kepala Dispenda Mimika, Paulus Yanengga kepada antara di timika, mengatakan tahun ini target penerimaan PAD Mimika sebagaimana yang ditetapkan DPRD setempat dalam APBD Tahun 2015 sebesar Rp.238,855 Milyar. Sedangkan Target APBD Tahun 2015 mencapai Rp.2.235 Triliun. Sumber: antarapapua.com 
Kabupaten Mimika merupakan salah satu kabupaten terkaya dengan keberadaan sumber daya alam yang mampu menciptakan sumber pendapatan daerah yang luas untuk mampu mendorong kemakmuran masyarakat kabupaten mimika. Untuk itu dengan kondisi faktual kabupaten mimika, maka pemerintah daerah perlu mengidentifikasi keunggulan Pendapatan Asli Daerah (PAD) sehingga optimalisasi dan identifikasi sumber-sumber pendapatan lainnya.

Dengan dasar ini maka peneliti sangat tertarik untuk memberikan kontribusi terhadap strategi peningkatan Pendapatan Asli Daerah (PAD), sehingga mampu di dorong oleh Pemerintah Daerah setempat. Dalam penelitian ini secara umum memiliki tujuan untuk mengkaji Pendapatan Asli Daerah (PAD) Kabupaten Mimika, adapun secara khusus memiliki tujuan sebagai berikut: (1) Untuk mengetahui sejauh mana potensi Pendapatan Asli Daerah (PAD) di Kabupaten Mimika Tahun 2004-2013; (2) Mengidentifikasi Faktor-faktor yang mendorong sumber pertumbuhan Pendapatan Asli Daerah (PAD) di Kabupaten Mimika.

Dalam beberapa peraturan perundang-undangan, yaitu UU Nomor 17 Tahun 2003 tentang Keuangan Negara, UU Nomor 1 Tahun 2004 tentang Perbendaharaan Negara, UU Nomor 15 Tahun 2004 tentang Pemeriksaan Pengelolaan dan Tanggung Jawab Keuangan Negara, UU Nomor 25 Tahun 2004 tentang Sistem Perencanaan Pembangunan Nasional, dan UU Nomor 33 Tahun 2004 tentang Perimbangan Keuangan antara Pemerintah Pusat dan Pemerintahan Daerah. Sebagai subsistem dari pengelolaan keuangan negara dan merupakan kewenangan pemerintah daerah, pelaksanaan pengelolaan keuangan daerah diatur dalam Peraturan Pemerintah (PP) Nomor 58 tahun 2005 tentang Pengelolaan Keuangan Daerah, yang mengatur secara komprehensif dan terpadu (omnibus regulation) ketentuan-ketentuan dalam bidang pengelolaan keuangan daerah, dengan mengakomodasi berbagai substansi yang terdapat dalam berbagai undang- undang diatas.

\section{METODE PENELITIAN}

Proses pelaksanaan kajian memakai pendekatan kuantitatif, pendekatan memiliki pengertian yakni metode penelitan yang bersifat deskriptif dan lebih banyak menggunakan analisis penelitan kuantitatif bertujuan mencari hu bungan yang menjelaskan sebab-sebab dalam fakta-fakta sosial yang terukur, menunjukan hubungan variabel serta menganalisa. Sedangkan sumber data utama yaitu dokumentasi serta studi kepustakaan. 


\section{HASIL DAN PEMBAHASAN}

Perkembangan Pendapatan Asli Daerah (PAD) di Kabupaten Mimika. Kabupaten Mimika memiliki 10 Objek pajak yang selama ini dilakukan pemungutan dari wajib pajak baik perorangan maupun lembaga. Pajak memiliki peran cukup besar bagi Pendapatan Asli Daerah (PAD) Kabupaten Mimika. Untuk lebih jelas dalam memotret Komponen Pajak Daerah, dapat melihat tabel sebagai berikut:

Tabel 1.1 Perkembangan Kondisi Komponen Pajak Daerah Kabupaten Mimika Tahun 2004-2013

\begin{tabular}{|c|c|c|c|c|c|c|c|c|c|c|}
\hline \multirow[b]{2}{*}{ Thn } & \multicolumn{10}{|c|}{ Komomponen Pajak Daerah } \\
\hline & Hotel & Restoran & $\begin{array}{l}\text { Hibura } \\
n\end{array}$ & $\begin{array}{c}\text { Reklam } \\
\text { e }\end{array}$ & $\begin{array}{c}\text { Penerangan } \\
\text { Jalan }\end{array}$ & $\begin{array}{c}\text { Mineral } \\
\text { Bukan } \\
\text { Logam } \\
\& \\
\text { Batuan }\end{array}$ & Parkir & $\begin{array}{c}\text { Air } \\
\text { Tanah }\end{array}$ & PBB & BPHTB \\
\hline 200 & $-41 \%$ & - & $142 \%$ & $52 \%$ & $368 \%$ & 4 & - & - & - & - \\
\hline 200 & 177 & $18 \%$ & $45 \%$ & $32 \%$ & 13 & $11 \%$ & - & - & - & - \\
\hline 200 & $-27 \%$ & $-11 \%$ & $-63 \%$ & $-13 \%$ & $199 \%$ & $31 \%$ & - & - & - & - \\
\hline 200 & $9 \%$ & $57 \%$ & $51 \%$ & $83 \%$ & 13 & 4 & - & - & - & - \\
\hline 200 & $61 \%$ & $28 \%$ & $80 \%$ & $58 \%$ & 4 & 0 & - & - & - & - \\
\hline 200 & $22 \%$ & $1 \%$ & $198 \%$ & $40 \%$ & 10 & $16 \%$ & - & - & - & - \\
\hline 201 & $-2 \%$ & $537 \%$ & $11 \%$ & $-9 \%$ & 0 & $14 \%$ & - & - & - & - \\
\hline 201 & $13 \%$ & $25 \%$ & $58 \%$ & $87 \%$ & $101 \%$ & $42 \%$ & - & - & - & - \\
\hline 201 & $14 \%$ & $33 \%$ & $63 \%$ & $48 \%$ & 94 & $135 \%$ & - & $137 \%$ & - & $-3 \%$ \\
\hline 201 & $3 \%$ & $-14 \%$ & $46 \%$ & $-6 \%$ & $-76 \%$ & $-85 \%$ & $-100 \%$ & $-100 \%$ & - & $-33 \%$ \\
\hline
\end{tabular}

Sumber: Data diolah, 2015

Pajak hotel terlihat memiliki pengaruh positif terhadap PAD Kabupaten Mimika, kecuali pada tahun 2004, 2006, dan tahun 2010 mengalami pertumbuhan yang negatif. Hal ini dapat disebabkan oleh wajib pajak atau pada pengelola Pajak Daerah (SKPD terkait). Pertumbuhan sangat signifikan pada tahun 2005 yang mengalami pertumbuhan diatas 100 persen dengan Realisasi Pajak Sebesar Rp.7 Milyar, pada tahun 2013 hanya mengalami pertumbuhan 3 persen dari tahun sebelumnya 2012, secara keseluruhan rerata pertumbuhan Pajak Hotel sebesar 23 persen dengan tanda positif.

Kondisi Komponen Retribusi Daerah. Kabupaten Mimika memiliki 3 Objek retibusi yang selama ini dilakukan pemungutan baik perorangan maupun lembaga. Retribusi memiliki peran cukup besar bagi Pendapatan Asli Daerah (PAD) Kabupaten Mimika. Untuk lebih jelas dalam memotret Komponen Retribusi Daerah, dapat melihat tabel sebagai berikut: 
Tabel 1.2 Perkembangan Kondisi Komponen Retribusi Daerah Kabupaten Mimika Tahun 2004-2013

\begin{tabular}{|c|c|c|c|}
\hline \multirow{2}{*}{ Tahun } & \multicolumn{3}{|c|}{ Komponen Retribusi Daerah } \\
\cline { 2 - 4 } & $\begin{array}{c}\text { Retribusi Jasa } \\
\text { Umum }\end{array}$ & $\begin{array}{c}\text { Retribusi Jasa } \\
\text { Usaha }\end{array}$ & $\begin{array}{c}\text { Retribusi Perizinan } \\
\text { Tertentu }\end{array}$ \\
\hline 2004 & $6 \%$ & $53 \%$ & $67 \%$ \\
\hline 2005 & $-19 \%$ & $48 \%$ & $16 \%$ \\
\hline 2006 & $2 \%$ & $197 \%$ & $-30 \%$ \\
\hline 2007 & $-2 \%$ & $-80 \%$ & $108 \%$ \\
\hline 2008 & $98 \%$ & $-9 \%$ & $13 \%$ \\
\hline 2009 & $353 \%$ & $-14 \%$ & $41 \%$ \\
\hline 2010 & $46 \%$ & $22 \%$ & $85 \%$ \\
\hline 2011 & $-12 \%$ & $-11 \%$ & $-28 \%$ \\
\hline 2012 & $-55 \%$ & $-8 \%$ & $-49 \%$ \\
\hline 2013 & $-27 \%$ & $-17 \%$ & $65 \%$ \\
\hline Rerata & $39 \%$ & $18 \%$ & $29 \%$ \\
\hline
\end{tabular}

Sumber: Data diolah, 2015

Retribusi jasa umum kurun waktu 2004-2013 memiliki pertumbuhan positif, dimana pada kondisi yang sama terjadi pertumbuhan negatif. Pada tahun 2012 terjadi penurunan pertumbuhan realisasi retribusi jasa umum sebesar 55 persen dari tahun sebelumnya. Pertumbuhan positif terjadi di tahun 2009 melebihi 100 persen yakni sebesar 353 persen. Rata-rata pertumbuhan retribusi jasa umum dikabupaten Mimika sebesar 39 persen.

Kondisi Komponen Kekayaan BUMD dan Asset. Kekayaan BUMD dan Asset Pemerintah Daerah yakni berupa Bagian Laba atas Penyertaan Modal BUMD di Kabupaten Mimika. Dimana bagian ini menjadi salah satu bentuk Pendapatan Asli Daerah (PAD), untuk mengetahui perkembangan dari kondisi dari obejek pendapatan asli daerah ini, dapat dilihat sebagai berikut:

Tabel 1.3 Perkembangan Bagian Laba Atas Penyertaan Modal BUMD Kabupaten Mimika Tahun 2004-2013

\begin{tabular}{|c|r|}
\hline Tahun & Bagian Laba Atas Penyertaan Modal BUMD \\
\hline 2003 & $600,634,688$ \\
\hline 2004 & $1,216,433,000$ \\
\hline 2005 & $3,796,971,332$ \\
\hline 2006 & $911,104,367$ \\
\hline 2007 & $1,771,752,521$ \\
\hline 2008 & $11,500,000$ \\
\hline 2009 & $5,069,537,059$ \\
\hline 2010 & $5,500,069,318$ \\
\hline 2011 & $4,195,402,211$ \\
\hline 2012 & $5,488,830,016$ \\
\hline 2013 & $6,038,699,124$ \\
\hline
\end{tabular}

Sumber: DISPENDA Kabupaten Mimika, 2015 
Kurun waktu 11 tahun rata-rata item memiliki share terhadap Pendapatan Asli Daerah (PAD) Kabupaten Mimika sebesar Rp. 3 Milyar. Dimana berdasarkan tabel diatas maka nampak pada tahun 2003 merealisasikan Rp.600 Juta pada tahun 2013 mengalami peningkatan yang cukup signifikan yakni sebesar Rp. 6 Milyar. Pada tahun 2006 terjadi penurunan realisasi penerimaan objek ini sebesar Rp.2 Milyar kondisi ini terjadi penurunan sangat drastis pada tahun 2008 yakni mencapai titik penurunan sebesar Rp.100 Juta.

Kondisi Kompenen Lain-lain Pendapatan Yang sah. Komponen Lain-lain Pendapatan Yang Sah di Kabupaten Mimika, antara lain sebagai berikut: (1) Hasil Penjualan Aset Daerah Yang Tidak Dipisahkan, (2) Penerimaan Jasa Giro, (3) Pendapatan Bunga Deposito, (4) Tuntutan Ganti Kerugian Daerah (Tgr), (5) Pendapatan Denda Pajak Pendapatan Denda Retribusi, (6) Pendapatan Dari Pengembalian. Untuk dapat mengetahui perkembangan masing-masing dari objek Lain-lain Pendapatan Yang sah, dapat mengamati tabel sebagai berikut:

Tabel 1.4 Perkembangan Lain-lain Pendapatan Yang Sah Kabupaten Mimika Tahun 2004-2013

\begin{tabular}{|c|c|c|c|c|c|c|c|}
\hline \multirow{2}{*}{$\begin{array}{l}\text { Tahu } \\
\mathrm{n}\end{array}$} & \multicolumn{7}{|c|}{ Komponen Lain-Lain Pendapatan Yang Sah } \\
\hline & $\begin{array}{c}\text { Hasil } \\
\text { Penjualan } \\
\text { Aset Daerah } \\
\text { Yang Tidak } \\
\text { Dipisahkan }\end{array}$ & $\begin{array}{c}\text { Penerimaan } \\
\text { Jasa } \\
\text { Giro }\end{array}$ & $\begin{array}{c}\text { Pendapatan } \\
\text { Bunga } \\
\text { Deposito }\end{array}$ & $\begin{array}{c}\text { Tuntutan } \\
\text { Ganti } \\
\text { Kerugian } \\
\text { Daerah } \\
\text { (Tar) }\end{array}$ & $\begin{array}{l}\text { Pendapatan } \\
\text { Denda } \\
\text { Pajak }\end{array}$ & $\begin{array}{c}\text { Pendapatan } \\
\text { Denda } \\
\text { Retribusi }\end{array}$ & $\begin{array}{c}\text { Pendapatan } \\
\text { Dari } \\
\text { Pengembalian }\end{array}$ \\
\hline 2004 & - & $-62 \%$ & - & - & - & - & - \\
\hline 2005 & - & $284 \%$ & - & - & - & - & - \\
\hline 2006 & - & $1161 \%$ & - & - & - & - & $-100 \%$ \\
\hline 2007 & - & $-63 \%$ & - & - & - & - & - \\
\hline 2008 & - & 2 & $350 \%$ & - & $186 \%$ & $-27 \%$ & $443 \%$ \\
\hline 2009 & $136 \%$ & - & 69 & - & $185 \%$ & $-40 \%$ & - \\
\hline 2010 & - & $-76 \%$ & $-19 \%$ & - & 32 & 20 & - \\
\hline 2011 & $511 \%$ & 4 & 54 & - & 81 & 99 & 24 \\
\hline 2012 & - & $-20 \%$ & $-21 \%$ & - & 81 & $-69 \%$ & - \\
\hline 2013 & - & 3 & $-29 \%$ & - & $212 \%$ & $521 \%$ & - \\
\hline
\end{tabular}

Sumber: Data diolah, 2015

Hasil penjualan aset daerah yang tidak dipisahkan memiliki pertumbuhan positif yang cukup besar pada tahun 2011 sebesar 511 persen atau sebesar Rp.1 Milyar. Namun dengan pencapaian tersebut, pada tahun 2012 dan 2013 secara berturut-turut mengalami penurunan realisasi penerimaan item ini masingmasing sebesar 31 persen dan 46 persen.

Potensi Pendapatan Asli Daerah (PAD) di Kabupaten Mimika Tahun 2004-2013. Peran dari komponen Pendapatan Asli Daerah (PAD) di Kabupaten 
Mimika sangat penting apabila di tinjau dari kontribusi pajak dalam Penerimaan PAD Kabupaten Mimika. Besar penerimaan pajak tahun 2004 mencapai Rp.10 Milyar dan pada tahun 2013 meningkat menjadi mencapai Rp. 97 Milyar, namun pada tahun 2012 Kondisi Pajak mampu merealisasikan penerimaan mencapai Rp.147 Milyar.

Tabel 4.7 Pertumbuhan Komponen Pajak \& Retribusi Kabupaten Mimika Tahun 2004-2013

\begin{tabular}{|c|c|c|c|c|c|c|c|c|c|c|c|c|}
\hline \multirow{2}{*}{ No } & \multirow{2}{*}{$\begin{array}{c}\text { Komponen } \\
\text { Pajak dan } \\
\text { RetribusiDaerah }\end{array}$} & \multicolumn{10}{|c|}{ Pertumbuhan Periode 2004-2013 } & \multirow{2}{*}{ Rerata } \\
\hline & & 2004 & 2005 & 2006 & 2007 & 2008 & 2009 & 2010 & 2011 & 2012 & 2013 & \\
\hline 1 & Pajak Hotel & -40.71 & 176.98 & -27.29 & 8.70 & 61.27 & 22.49 & -2.06 & 13.02 & 14.01 & 3.28 & 22.97 \\
\hline 2 & Pajak Restoran & -2.71 & 18.01 & -11.17 & 56.54 & 27.66 & 0.78 & 536.52 & 25.30 & 32.90 & -13.66 & 67.02 \\
\hline 3 & Pajak Hiburan & 141.60 & 44.75 & -63.10 & 51.18 & 80.10 & 198.25 & 10.74 & 57.70 & 63.02 & 45.52 & 62.98 \\
\hline 4 & Pajak Reklame & 52.30 & 32.46 & -12.81 & 83.19 & 57.70 & 39.95 & -8.79 & 87.02 & 47.90 & -5.94 & 37.30 \\
\hline 5 & $\begin{array}{l}\text { Pajak } \\
\text { Penerangan } \\
\text { Jalan }\end{array}$ & 367.66 & 12.80 & 198.94 & 13.27 & 3.80 & 10.05 & 0.25 & 100.95 & 94.09 & -76.12 & 72.57 \\
\hline 6 & $\begin{array}{l}\text { Pajak Mineral } \\
\text { Bukan Logam } \\
\text { \& Batuan }\end{array}$ & 3.55 & 10.67 & 30.77 & 3.65 & -0.42 & 16.07 & 14.09 & 41.80 & 135.40 & -85.14 & 17.04 \\
\hline 7 & $\begin{array}{l}\text { Retribusi Jasa } \\
\text { Umum }\end{array}$ & 5.68 & -19.20 & 1.94 & -1.79 & 98.18 & 353.37 & 46.26 & -12.16 & -54.72 & -26.70 & 39.09 \\
\hline 8 & $\begin{array}{l}\text { Retribusi Jasa } \\
\text { Usaha }\end{array}$ & 52.60 & 47.75 & 196.86 & -80.30 & -9.44 & -13.86 & 22.23 & -11.43 & -7.59 & -16.62 & 18.02 \\
\hline 9 & $\begin{array}{l}\text { Retribusi } \\
\text { Perizinan } \\
\text { Tertentu } \\
\end{array}$ & 66.69 & 15.56 & -30.12 & 108.44 & 12.64 & 41.44 & 85.33 & -27.64 & -48.96 & 65.19 & 28.86 \\
\hline
\end{tabular}

Sumber: Data diolah, 2015

Dalam penelitian ini, terdapat 9 komponen Pendapatan Asli Daerah di Kabupaten Mimika, dimana sebanyak 6 jenis komponen pajak daerah dan 3 jenis komponen retribusi daerah. Terlihat pada tabel diatas bahwa Pajak hotel mengalami pertumbuhan negatif pada tahun 2004, 2006,dan 2010 masingmasing sebesar $-40,71$ persen, $-27,29$ persen, dan -2,06 persen dengan rata-rata pertumbuhan sebesar 22,97 persen.

\section{KESIMPULAN DAN SARAN}

\section{Kesimpulan}

Berdasarkan klasifikasi menggunakan shift dan share analisis maka potensi komponen pajak dan retribusi di Kabupaten Mimika, menunjukkan pada klasifikasi Prima yakni Retribusi Jasa Umum, dan Retribusi Perizinan Tertentu, sedangkan pada klasifikasi Berpotensi yakni Retribusi Jasa Usaha, untuk klasifikasi Berkembang Pajak Restoran, Pajak Hiburan, Pajak Reklame, Pajak 
Penerangan Jalan dan klasifikasi Terbelakang yakni Pajak Hotel, Pajak Mineral Bukan Logam \& Batuan.

Berdasarkan perhitungan elastisitas pajak terhadap Pendapatan Asli Daerah maka, diperoleh informasi bahwa sumber pertumbuhan melalui komponen Pendapatan Asli Daerah (PAD) yakni rerata komponen Pajak Daerah memperoleh penilaian Elastis, Retribusi Daerah memperoleh penilaian Inelastis, Laba BUMD dan Aset Daerah memiliki penilaian Unitary Elastis, dan komponen Lain-lain Pendapatan Yang Sah memperoleh penilaian Elastis. Sehingga melalui informasi ini, maka sumber pertumbuhan Pendapatan Asli Daerah di Kabupaten Mimika di persembahkan oleh komponen Realisasi Pajak Daerah, Laba BUMD dan Aset Daerah.

\section{Saran}

Pemerintah Daerah perlu meningkatkan penerimaan Pendapatan Asli Daerah dari pos peneriman yang memiliki potensi yang besar melalui Retribusi Jasa Usaha, dan juga konsisten mengembangkan Pajak Restoran, Pajak Hiburan, Pajak Reklame, Pajak Penerangan Jalan, dan memperhatikan Pajak Hotel, Pajak Mineral Bukan Logam \& Batuan sehingga dapat mengoptimalkan Pos Penerimaan di Kabupaten Mimika.

Peningkatan Pajak Hotel melalui penetapan tarif pajak bagi setiap pemilik losmen maupun rumah sewa serta hotel melati tiga karena setiap penghasilan yang diterima wajib dikenakan pajak.

Upaya kerjasama lintas SKPD dalam rangka menggali dan mengoptimalkan sektor-sektor penyumbang Retribusi, dalam rangka meningkatkan peran retribusi dalam pembentukan nilai Pendapatan Asli Daerah.

Kebijakan optimalisasi terkait penerimaan Laba BUMD dan Aset Daerah mengenai Dividen Bank Papua, sehingga mampu memberikan kontribusi positif terhadap Pendapatan Asli Daerah di Kabupaten Mimika.

Peningkatan pengawasan dan supervisi pada seluruh objek komponen Pendapatan Asli Daerah, melalui dukungan regulasi daerah untuk dapat meningkatkan penerimaan daerah.

Dalam menjaga pertumbuhan dan kontribusi Komponen Pendapatan Asli Daerah (PAD) maka perlu dilakukan kebijakan intensifikasi dan ekstensifikasi di Kabupaten Mimika. 


\section{DAFTAR PUSTAKA}

Baridwan, Zaki. 1998. Sistem Akuntansi: Penyusunan Prosedur dan Metode Yogyakarta: BPFE.

Imam Gunawan, Metode Penelitian Kualitatif (Teori dan Praktik), PT. Bumi Aksara, Jakarta, 2013

Imam Soebechi, JUDICIAL REVIEW (Perda Pajak dan Retribusi Daerah), Sinar Grafika, Jakarta, 2013

Imam Ghozali, Ekonomitrika, UniversitasDiponegora, Semarang, 2009

Jogiyanto H.M, Metode Penelitian Bisnis (Salah Kaprah dan Pengalamanpengalaman), Edisi Pertama, BPFE-Yogyakarta, 2010.

Mamesah, D, J. 1995. Sistem Administrasi Keuangan Daerah. Jakarta: Pustaka Utama

Mardiasmo, Perpajakan Edisi Revisi 2011, ANDI, Yogyakarta, 2011

Marihot Pahala Siahaan, Hukum Pajak Material ( Objek, Subjek, Dasar Pengenaan Pajak, Tarif Pajak, dan Cara Perhitungan Pajak), Edisi Pertama, Graha IImu, Yogyakarta, 2010

Muhhamad. Faktor-faktor Yang Mempengaruhi Pendapatan Asli Daerah di Samarinda, Tahun 2005

Nick Devas, Brian Binder, Anne Booth, Kenneth Davey, Roy Kelly, Keuangan Pemerintah Daerah di Indonesia, Penerbit Universitas Indonesia (UIPress), Salemba 4 Jakarta, 1987.

Singgih Santoso, Menguasai SPSS 21 di Era Informasi, PT. Elex Media Komputindo, Jakarta, 2013

Subhan, Analisis Faktor-Faktor Yang Mempengaruhi Tingkat Pendapatan Asli Daerah (PAD) Kabupaten Banyumas, Tahun 2010

Sigit, Analisis Penerimaan Retribusi Pelayanan Kesehatan" (Studi Kasus di Kabupaten Boyolali), Tahun 2004

Transna ,Pengaruh Pengeluaran Pemerintah dan Perkembangan Ekonomi Terhadap PAD di Provinsi Papua, Tahun 2004

Peraturan Pemerintah Nomor 58 tahun 2005, tentang Pengelolaan Keuangan Daerah

Purwadinata, Analisis Potensi Pendapatan Asli Daerah Dan Strategi Peningkatan Kemampuan Keuangan Daerah (Di Kabupaten Sumbawa), Tahun 2010

Robinson Tarigan, Ekonomi Regional (Teoridan Aplikasi), PT. BumiAksara, Jakarta, 2005 
Riduansyah, Kontribusi Pajak Daerah dan Retribusi Daerah Terhadap Pendapatan Asli Daerah (PAD) dan Anggaran Pendapatan dan Belanja Daerah (APBD) Guna Mendukung Pelaksanaan Otonomi Daerah "(Studi Kasus Pemerintah Daerah Kota Bogor), Tahun 2002

Undang-Undang Nomor 23 Tahun 2014 Tentang Pemerintahan Daerah

Undang-Undang Nomor.33 Tahun 2004 Tentang Perimbangan Keuangan

Undang-Undang Nomor 17 Tahun 2003 Tentang Keuangan Negara Undang

Undang Nomor 1 Tahun 2004 Tentang Perbendaharaan Negara

Undang-Undang Nomor 15 Tahun 2004 Tentang Pemeriksaan Pengelolaan Dan Tanggungjawab Keuangan Negara

Undang-Undang Nomor 25 Tahun 2004 Tentang Sistem Perencanaan Pembangunan Nasional

Undang-Undang Nomor 28 Tahun 2009 Tentang Pajak Daerah dan Retribusi Daerah

YuliaYustikasari, Pengaruh Pertumbuhan Ekonomi, PAD dan DAU Terhadap Pengalokasian Anggaran Belanja Modal, Tahun 2007

Wahidi, Analisis Fakaktor-faktor yang mempengaruhi Pendapatan Asli Daerah di Propinsi Kalimantan timur, Tahun 2003 